\title{
Childhood and biopolitics in the 2 I st century: a scenario yet to bedescribed
}

\begin{abstract}
This study aims to reflect on bio power in relation to children. Childhood is deemed to be an almost idyllic and sacrosanct period in the life cycle of the human subject, but one which comprises one of the most fertile scenarios for bio power. Here we give a brief overview of the theoretical considerations about bio power and its action in childhood, and a small review of two fundamental aspects in the 21 st century: pharmacised children and technician children.
\end{abstract}

Volume 2 Issue 6 - 2018

\author{
Carmen Gaona Pisonero, Almudena Garcia \\ Manso
}

Department of Sociology, University of Rey Juan Carlos, Spain

Correspondence: Carmen Gaona Pisonero, Department of Sociology, University of Rey Juan Carlos, Spain, Email carman.gaona@urjc.es

Received: December 05, 2017 | Published: November 30, 2018

\section{Introduction}

\section{Childhood and biopolitics: an inseparable relationship}

The universe of children has changed, the proposals and demands of the adult world regarding childhood, this are different to any other time in history. ${ }^{1}$ Nowadays, to refer to childhood is to refer to one of the periods in the life cycle of the subject that is most fertile in representations; there is an intense subjective and social implication. Childhood has always been a focus of theoretical references, disciplines and practices, which makes it more complicated to tackle it, whether from an anthropological, sociological, political, medical or economic perspective. Childhood is considered in present Western society to be an almost idyllic period through which the subject passes without trouble or fanfare; the infant of today is not deemed a subject in the grip of a sea of troubles, doubts, complexes and vital suppositions which it has to face. Childhood in some Western societies is more a period that is intrinsically linked to an innocent and tender age which is asexual, incomplete and wholly separate from the social universe of adults. However, this vision is too far removed from what childhood really is and is understood to be, that key period of our lifecycle for shaping our adult personality (from the most Freudian perspective in the relationship between infancy and psychoanalysis) and the period in which biopolitics begins to act, deploying the mechanisms and technologies that are skilful at shaping the adult subject. From the more traditional perspective of pedagogy-one of the most influential power mechanisms in reference to infancy-the 20th century saw a child as a miniature adult, and its efforts focused on making these little ones future responsible men and women, efforts that translated into the hidden, institutional curriculum deployed in schools. ${ }^{2}$

Pedagogy and the school, bio power mechanisms, marked a milestone in the more individual and personalised bio political constitution of childhood-the mechanisms applied to the child were not those applied to the adults. These, the children, should have an independent and appropriate space to become the future citizens. This is how school "had much to do with the demarcation of childhood both through the dissemination of a psychological discourse.... and through the expansion of an idea of minority-incompleteness- immaturity that placed childhoodin a subordinate place, whose voice and perspectives ought not be taken into account". School is a disciplinary environment with appropriate power mechanisms to shape the citizens of tomorrow according to the guidelines proposed by power. This shows us that childhood is a stage in life that is equally sustained, contained and constructed in a body that is individual, not common. That body occupies a space, acquires a meaning and needs its own identity, but is mediatised by disciplines and mechanisms that are bio power techniques that will to guide it along the path of normativity.

Here is not the place for an in-depth study of schools and their bio political relationship in the shaping of the subjects-bodies during childhood, but there is room to highlight that the development of pedagogic science, child psychology and pedagogical innovations, as well as the continuous restructuring that the education system has experienced, are a demonstration of the great bio political capacity of the school, a bio political social institution that chisels subjects that are growing socially, subjectively, politically and bodily. ${ }^{4}$

However, the construction of reality is also formed in other social environments and institutions, not just in schools. In the construction of normative reality, the philosophical conception of Agamben about infancy enters into play. Agamben considers infancy to be a period that transcends a certain age viewed as part of the development of biological maturity, with infancy being a non-place of language. Therefore, infancy could be considered from this perspective as an individual experience "...difference between the human and the linguistic...the individual as not already speaking, as having been and still being an infant - this is experience". ${ }^{5}$ This means a complex existential dynamic between the living subject and language, a dynamic where the experience gains shape in the formation of language, an experience that is regulated, guided and monitored by the institutions and power technologies that make that language possible. Hence, the human subject "by having an infancy, by preceding speech, splits this single language and, in order to speak, has to constitute himself as the subject of language - he has to say I". ${ }^{5}$ Therefore, from this perspective, infancy is the possibility of appropriating the signs so that there is an enunciation behind which is the subject, who, to 
preserve his infancy, can speak of himself as living. In conclusion, in Agamben $^{5}$ idea of infancy, we can see that the subject is not always linked to language, but appropriates it, while however always having a space linked to creation, to autonomy, to individual existence, to infancy. This is why childhood is always represented as a period in the life cycle where subjects repeat, reiterate and create situations which they have taken, as a reflection/mirror, from adult life. Gender roles, violent and affective relationship, irrational preferences and phobias will be closely linked to what is represented by the adults close to them. Even so, they are not completely ascribed to an adult social order that is conveyed by a language, by a discourse. Therefore, childhood has been gaining in importance in the interests of hegemonic discourse, as it is the subjects' capacity for free creation that calls into question and casts doubt on hegemonic control mechanisms. "....in every society the production of discourse is at once controlled, selected, organized and redistributed by a certain number of procedures, whose role is to avert its powers and its dangers, to cope with chance events, to evade its ponderous, awesome materiality". ${ }^{6}$

This is one of the reasons why childhood is so attractive; its capturing and subsequent adaption to hegemonic discourses and narratives means makes them necessary in the subsequent staging of the subject subjected to the social order in an accelerated consumption-production society. ${ }^{7}$ Infancy is reborn in this respect as one more dimension to control for biopolitics. Language and experience are two of the elements necessary to shape the living subject. Shared language introduces common culture, a non-neutral culture that acts as a mediator and fine-tunes lifestyles in order to transform them into shared and normative lifestyles. ${ }^{8-10}$ This operation starts off being political-anatomical and leads to the biopolitics of the population: all the subjects under the same parameters and all biologically programmed in an identical and predetermined manner, and predisposed for the same purposes. ${ }^{11-16}$

Childhood as a stage of the hegemonic discourse dangerous to life is considered, implying that childhood, to be captured and treated through mechanisms, techniques and discourses that conform and transform it into a mere period flooded by what is classical Greek philosophy was understood as bios, denoting a life that is qualitatively differentiated and inscribed within the polis, towards zoe, naked life devoid of any subjectivity. ${ }^{16-20}$ It is in this strategy of capturing and excluding childhood, all this being mediated by language, where the living subject, already articulated by an acquired language from outside its experiences, is reduced to a naked life, to a biological body that has no individuality and that has to group together with and normalise itself in relation to what is usual. This is a zoe that shows a life that has been reduced to economic, political, domestic and social calculations; a life that excludes the individual experience of the subject, possibly acquired during infancy, although this does not mean the complete cancellation of individual will and the existence of a creative, revelatory and autonomous subjectivity of the living subject. ${ }^{21-24}$

However, naked life, which initially could seem to be outside the polis, is part of the political game through the control techniques and the technologies of the self projected from the legal and governmental frameworks of the different social institutions and operators of power and control. In this respect, the Charter of Children's Rights, ${ }^{25}$ together with the legal frameworks of each country, establishes the perfect cushion to enable the naked flesh, the naked life, you can become a political and normative life. Agamben states that this de-subjetivisation of infancy comes from an exclusion/inclusion in the power and control mechanisms established by sovereignty, highlighting that this conversion is born out of "something is included solely through its exclusion". ${ }^{5}$ (duda-not in Homo Sacer 1998/2003 El Homo sacer?).

In short, the childhood of the living subject is a period captured by bio political mechanisms with the purpose of being de-politicised in respect of its own subjective politics (that which is created before the acquisition of the common language and is based on experiences); the living subject is taken from bios to zoe, administrated anonymously as a demographic figure and a normative body. Infancy passes through two phases, that of defence and preservation and that of hostility and intrusion, infliction and subjugation. These two spheres appear to coexist, given that from the most critical vision of society, biopolitics invades everything, even childhood itself that so defended and revered childhood.

\section{Conclusion}

Throughout this article, although we have alluded to the idyllic image of Haraway's cyborg, our theoretical approach has been based on untangling the cyber socialisation process, which also involves boys and girls. We have described the cyber socialisation of the individual, showing the narratives of normativity. This idea is very different from the "most beautiful utopia that humanity has been able to conceive: the possibility of shaping (and shaping the destiny of) one's own self. The cyborg forgets the past and builds the future. The cyborg-inevitably associated with representing the monstrous and anti-natural construction that is released from the norm-is the incarnation of difference. The question, however, continues to be the same: Can the discourse of difference also be released in it? Bodies change but ideologies persist". ${ }^{26,27}$

Perhaps the incorporation of cyborg life could save us from subjection to the bio power. This causes us to reflect on how the mechanisms of the current bio power can have adverse effects for hegemonic discourses. ${ }^{29,30}$ The plasticity and change in the living subjects and their bodies, through pharmacopornographic powers, can be projected as strategies to transgress normativity. Although these strategies would not be completely ethical and valid in childhoodwe are talking here of transgression through corporal modificationsthe creative ability (as described by Agamben in relation to infant subjectivity, ${ }^{31}$ a subjectivity that is based on experiences and is far removed from hegemonic language) could be invoked, moving away from the technologies of power. Even so, we continue to be in a society where the narratives and the languages that constitute all that is hegemonic continue to dominate through bodies, stressing childhood as a social space of great significance in the life cycle of the living subject-they are the citizens of the future. ${ }^{32,33}$

\section{Acknowledgments}

None.

\section{Conflicts of interest}

The author declares there is no conflicts of interest.

\section{References}

1. Levin E. ¿Hacia una Infancia Virtual? La imagen corporal sin cuerpo. Buenos Aires: Editions Nueva Edición; 2006. 3 p. 
2. Nadoroski M. Dolor de escuela. Buenos Aires: Prometeo booka; 2006.154 p.

3. Dussel I, Southwell MY. La niñez contemporánea. Aportes para repensar a los sujetos de la escuela. Buenos Aires: Ministry of Education, Science and Technology; $2006.515 \mathrm{p}$.

4. Baño JF. La escuela de la multitud. Una lectura pedagógica de los textos de Antonio Negri. Valencia: University of Valencia, Service Publications; 2010. 802 p.

5. Agamben. Infancia e historia: destrucción de la experiencia y origen de la historia. In: Adriana Hidalgo, editor. Buenos Aires: 2004. 111 p.

6. Foucault M. El orden del discurso. 1st ed. Madrid: Editions Endimión 1996. 12 p.

7. Bauman Z. Mundo consumo. Barcelona: Paidós; 2010. 250 p.

8. Amnistía Internacional. Con la violencia hacia las mujeres no se juega. In Videojuegos, discriminación y violencia contra las mujeres. 2004. 39 p.

9. Ballesteros Jesús, Fernández Encarnación. Biotecnología y posthumanismo. Madrid, Editorial Aranzadi; 2007. 503 p.

10. Baudrillard J. Pantalla total. Barcelona: Anagrama; 2000. 35 p.

11. Berardi F. Generación post-alfa. Patologías e imaginarios en el semiocapitalismo. Buenos Aires: Tinta Limón Editions; 2010. 220 p.

12. Beriain J. Modernidades en disputa. Barcelona: Antrophos; 2005. 338 p.

13. Bonder G. Las nuevas tecnologías de información y las mujeres. reflexiones necesarias. Santiago de Chile: Publication of the United Nations; 2002. 54 p.

14. Canelotto A. Medicalización y sociedad. Lecturas críticas sobre un fenómeno en expansión, Buenos Aires, Editorial UNSAM; 2010. 181 p.

15. Deleuze G. Foucault. Barcelona: Paidós; 1991.169 p.

16. Duek C. Infancia, Fast food y consumo (o cómo ser niño en el mundo Mcdonald's). In: Carli S, editor. La cuestión de la infancia. Entre la escuela, la calle y el shopping. Buenos Aires, Paidós; 2006. 307 p.

17. Federici S. Caliban y la burja. Mujeres, cuerpo y acumulación originaria. Madrid: Editorial Traffickers Dreams; 2010. 367 p.
18. Foucault M. Vigilar y castigar. Nacimiento de la prisión, Madrid: Siglo XXI; 1994.305 p.

19. Foucault M. Los anormales. Mexico DC, Fondo de cultura económica; 2006. 350 p.

20. Foucault M. Nacimiento de la biopolítica. Madrid: Akal; 2009. 352 p.

21. Gallego Ayala J. Eva devuelve la costilla: El Nuevo Estado de Conciencia de Las Mujeres. Barcelona, Icaria; 2010.2010 p.

22. Latour B. La esperanza de Pandora. Ensayos sobre la realidad de los estudios de la ciencia. Barcelona: Gedisa; 2001.

23. Le Breton D. Antropología del cuerpo y modernidad. Buenos Aires: Nueva Visión; 1995.129 p.

24. Agamben. El Homo sacer. El poder soberano y la nuda vida. 1st ed. Valencia: Pre-textos; 2003. 286 p.

25. Marinas JM. La Fábula del Bazar. Orígenes de la cultura de consumo. Madrid: Machado Books; 2001. 264 p.

26. Martínez Collado A. Tecnoliberación. Ya somos Cyborgs. Rizomas; 2007.126 p.

27. Palermo G. El mito del mercado global. Crítica de las teorías neoliberales. Barcelona: El viejo topo; 2008. 254 p.

28. Piscitelli A. Nativos digitales: dieta cognitiva, inteligencia colectiva y arquitecturas de la participación. Buenos Aires: Santillana; 2009. 16 p.

29. Preciado B. Testo Yonki. Madrid: Espasa-Calpe; 2008. 6 p.

30. Preciado B. Pornotopia. Arquitectura y sexualidad en "Playboy" durante la guerra fría. Barcelona: Anagrama; 2010. 236 p.

31. Stiglitz G. DDA, ADD, ADHD, como ustedes quieran. El mal real y la construcción social. Buenos Aires: Grama; 2006. 186 p.

32. Wajcman G. El ojo absoluto. Buenos Aires: Manantial; 2011. 275 p.

33. Mcluhan M. Comprender los medios de comunicación. Barcelona: Paidós; 2009. $182 \mathrm{p}$. 